\title{
Evaluation the Correlation Between Pathogenic Microorganisms on Cultured Clam Meretrix SP. and Disease Incidence
}

\author{
Nguyen Duc Minh ${ }^{1}$, Le Ngoc Hanh ${ }^{1}$, Nguyen Thuy $\operatorname{Linh}^{2}$ \\ ${ }^{1}$ Faculty of Biological Technologies, Research Institute of Aquaculture No. 2, Ho Chi Minh City, Viet Nam \\ ${ }^{2}$ Faculty of Resources Management, Thai Nguyen University Agriculture and Forestry, Thai Nguyen City, Viet Nam
}

Email address:

ngochanhts@gmail.com (Le N. Hanh)

\section{To cite this article:}

Nguyen Duc Minh, Le Ngoc Hanh, Nguyen Thuy Linh. Evaluation the Correlation Between Pathogenic Microorganisms on Cultured Clam Meretrix sp. and Disease Incidence. Agriculture, Forestry and Fisheries. Vol. 9, No. 4, 2020, pp. 97-104. doi: 10.11648/j.aff.20200904.11

Received: May 18, 2020; Accepted: June 11, 2020; Published: June 20, 2020

\begin{abstract}
The study was carried out to determine the density of Vibrio sp. and Perkinsus $s p$. in cultured clams and evaluate the correlation between pathogenic microorganisms and disease incidence of white clams (Meretrix Lyrata) in Mekong Delta from March to May 2019. Clam samples were collected in different four regions (Ben Tre, Tra Vinh, Bac Lieu, and Tien Giang provinces) and there was mass mortality of clam in Tra Vinh province in May. In this assay, determination of the Vibrio sp. density was performed using Vibrio $s p$. selective Thiosulfate Citrate Bile Salt agar plates. Also, the Perkinsus $s p$. was cultured in Fluid thioglycollate medium to isolating the spore that effect to harmful for cultured clam. Then, T-test and one-way ANOVA analysis were used to access the impacts of those parameters on the clam health. Clams did not show specific clinical signs, and histological results showed minor injuries on their shells and gills. Correlation analysis revealed some biotic components related to clam health status; they were several Vibrio bacteria in clams were in the range of $0-2.23 \times 10^{5}(\mathrm{CFU} / \mathrm{g})$. The presence of Perkinsus sp. was detected in the clam tissue with a prevalence of $53 \%$ of the ratio of infection and the infection intensity of 4.08-57.43 (spores/g). However, the density of Vibrio $s p$. and the ratio of infection of Perkinsus $s p$. on clam was no significant difference on outbreak disease and non-outbreak disease factor on clam samples $(\mathrm{P}>0.05)$ in the clam samples. Thus, dead clams can be caused by several other factors.
\end{abstract}

Keywords: Venerid Clams, Meretrix Lyrata, M. Meretrix

\section{Introduction}

\subsection{Clam Production in Vietnam}

Venerid clams, especially the two species Meretrix Lyrata, and M. Meretrix have long been commonly cultivated in Vietnam and provide an important protein source for the local population. They are endemic to Vietnam's estuaries and coastal areas and can be found all over the country, from the Northern provinces to $\mathrm{Ca} \mathrm{Mau}$ Cape in the South. In particular, the clam which originates from Ben Tre is an important commercial species in the coastal areas for domestic and export markets (Directorate of Fisheries, 2011). More specifically, Meretrix Lyrata is widely distributed in southern provinces such as Go Cong (Tien Giang), Binh Dai, Ba Tri, Thanh Phu (Ben Tre), Cau Ngang, Duyen Hai (Tra Vinh), Vinh Chau (Soc Trang),
Vinh Loi (Bac Lieu), Ngoc Hien (Ca Mau) and Can Gio (Ho Chi Minh city). Meanwhile, M. Meretrix is naturally distributed in Northern Vietnam (for instance Nam Dinh, Ninh Binh, Thai Binh)[1]. However, since 1998, M. Lyrata has been introduced to aquaculture in the North of Vietnam because of the decline in Northern indigenous clam production.

Before 1980, Vietnam's production-of-clams were mostly from wild population harvest and at approximately $300-400$ tons/year [2]. An only small proportion was from clam farming which was initiated in the early 1970s. With the practice beginning to spread to nearby provinces such as Tien Giang, Tra Vinh, and Ho Chi Minh city. Vietnam's clam production increased significantly to about $700-800$ tons/year between 1982-1986. In the early 2000s, total production of clams from the Mekong Delta and Ho Chi Minh City regions were reported at 70,000 - 80,000 
tons/year [2]. Distributions of farming areas and regional production varied significantly from one region to another. While clam aquaculture in the northern locales produces a remarkably higher yield per hectare, the total culturing area in Southern provinces are several times higher than that in Northern provinces and thus, result in much higher total production.

\subsection{Disease in Clam Farming in the Mekong Delta}

Southern Vietnam's Mekong Delta area has high coastal aquaculture potential, including mollusc culture. Many mollusc species, including white clams (Meretrix Lyrata), are cultivated for national and export markets. The clam Meretrix Lyrata is a traditional source of high nutritional food and offers jobs for local individuals in coastal regions. Furthermore, disease outbreaks in commercial clam farming in recent years has caused many difficulties in capital sources to continue investing in clam farming. In 2010-2011, the disease outbreak occurred in about 759 ha (90\% of the farming area) in Can Gio, and resulted in approximately 2,595 tons of clam dead which valued at about 80 billion VND (Can Gio District Economic Department, Ho Chi Minh City Department of Quality Assurance and Aquatic Resource Protection, 2010).

However, the causes of diseases were unknown. At present many factors contribute to clam diseases such as flooding and freshwater effluents and siltation or sedimentation from the Mekong River. These environmental factors trigger clam mortality. Besides, in 2010-2012, mass clam mortality occurred in Tien Giang and caused losses of 220 billion VND [3]. Disease outbreaks continued in Ca Mau in 2016 and led to losses of 20 billion VND. Especially, the causes of disease on clam in Vietnam's aquaculture can be chiefly attributed to Vibrio bacteria and the alveolates, protists of the genus Perkinsus. Parasite Perkinsus sp. (P. marinus, P. olseni, P. honshuenis, P. chesapeaki, P. qugwadi, P. mediterranues) have been found and identified as the cause of death for different mollusc objects including clam Meretrix sp. [4]

\subsection{Major Infectious Diseases in Clam Farming}

\subsubsection{Vibrio sp. Infection in Clam Farming}

Vibrio is a major threat to aquaculture of marine animals. Vibrio bacteria are considered the main cause of clam death in larval and post-larval stages [5-6]. A typical example of Vibrio ( $V$. splendidus, $V$. alginolyticus) caused the mortality rate of $62-73 \%$ in $R$. decusstatus larvae in Spain [7]. The bacterial disease on commercial clams was is brown ring disease, which is caused by Vibrio tapei, and the infection rate over $90 \%$. According to Bondad-Reantaso et al., (2001) [8], the bacteria invade and damage membranes, then they enter the circulatory system to infect internally organs, causing the host to die from a blood infection. This disease has killed over $90 \%$ of commercial clams Ruditapes philippinarum in Korea [9-10] and Tapes descussates in Europe [11].

Furthermore, $V$. parahaemolyticus is also considered to be the main cause of death for adult clams M. Meretrix cultured in China in 2007. The ratio of clams infected by $V$. parahaemolyticus during disease outbreak was much higher than that ratio during non-disease period, $80 \%$ and $15 \%$, respectively [12]. All clams infected with this type of bacteria often had clinical signs including microvesicular fatty liver, V. parahaemolyticus is mainly found in brackish and saltwater.

\subsubsection{Parasite in Clam Farming}

Protozoan parasites mainly infect oyster and clam species, causing enormous damage to commercial productions. In particular, the diseases caused by Perkinsus marinus, Perkinsus olseni, Marteilia refringens, B. ostreae and $B$. exitiosa that are now under surveillance. Prevalence and intensity of infections tend to increase during the warm season, depending on temperature and high salinity. Perkinsus, especially Perkinsus marinus, was the first protozoan parasite that found on cultured molluscs. They were discovered on oysters in the Gulf of Mexico.

According to Villalba et al., (2004) [13], Perkinsus was originally classified as Phylum: Apicomplexa, Class: Perkinsea, Order: Perkinsida, Genus: Perkinsus. However, Blackbourn et al., (1998) [14] and some authors later claimed that Perkinsus species have both the characteristics of Apicomplexa and Dinoflagellate. So they were classified into a new phylum called Perkinsozoa. Perkinsus has only a single life cycle of three stages: trophozoite, hypnospore and zoospore, that taking place inside and outside the host [15]. The first stage is the zoospore. The zoospore is motile, which means that it can swim freely in the water by moving its two flagella. The host ingests the zoospore, which then becomes a trophozoite. The non-motile trophozoite multiplies in a vegetative form within the host tissue.

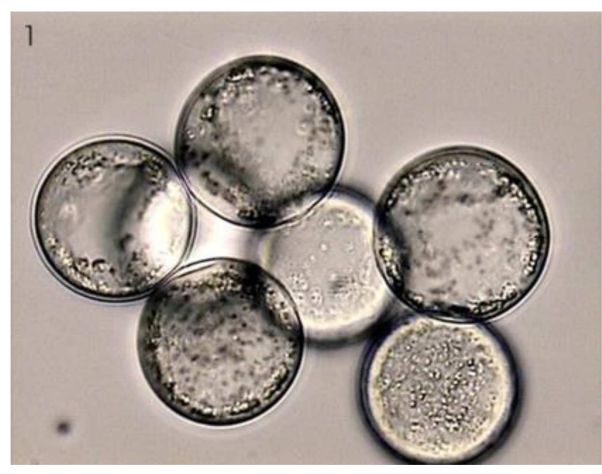

Figure 1. Perkinsus trophozoite.

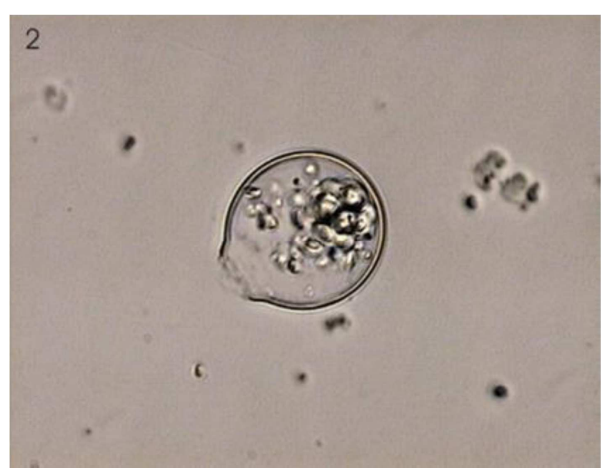

Figure 2. Perkinsus zoospore. 
This parasite often causes disease in environmental conditions with temperatures above $20^{\circ} \mathrm{C}$ and salinity above $15 \%$. Perkinsus $s p$. usually parasitic on gills, membrane coat, intestinal epithelial cells, connective tissue organizations of the gastrointestinal tract and gonads of the mollusk. The pathogen infects the hemocytes, multiplies within blood cells and spreads to all tissues. In highly infected adult oysters, we can find a yellow discolouration of the tissue that the major clinical sign, extensive lesions on the gill and mantle, breakdown of connective tissue and significant mortality $(>90 \%)$. Larvae can be infected and contribute to the spread of the parasite. A lack of resistance to infection and, therefore, high densities of oysters in closely-spaced beds favour the development of epizootics.

In the world, this type of agent has been studied on many bivalve molluscs such as oysters, mussels, scallops, clams and recently on silk clams. In Vietnam, Ngo Thi Thu Thao, (2008) [16] discovered Perkinsus sp. on silk clams (Paphia undulata) in the coastal areas of Kien Giang and Ba RiaVung Tau. In 2007, Perkinsus olseni was also discovered on Vietnam's mussel (Tridacna crocea) exported to the United States for ornamental purposes [17]. In 2010, P. olseni was also discovered in the Meretrix Lyrata clams - a common commercial bivalve mollusc in the coastal areas of Vietnam. There are many methods used to detect the presence of Perkinsus sp. such as histological method, observed by an electron microscope, cultured in Fluid thioglycollate medium (FTM), immunological methods and PCR.

Currently, culture method using Fluid thioglycollate medium is often employed to detect Perkinsus sp. in clams in Europe and Asia. To determine the density of Perkinsus infection on molluscs, whole culture method in Fluid thioglycollate medium with $\mathrm{NaOH} 2 \mathrm{M}$ is used to isolate spores. This method can detect the low density of Perkinsus, with only a few Perkinsus cells in clam individuals.

\subsubsection{Problems Related to Environment}

Besides pathogens like bacteria, virus, parasite, the environment is also an important factor that leading to an outbreak of mortality in clam farming.

Temperature is the most significant physical factor that can influence immune response, physiological reaction, embryonic development, growth, and survival of organisms. Exceeding temperature tolerance limits causes physiological disorders that result in clam death [18]. Lin and Xu (1997) [19] found that the survival rate of clams was higher at low temperatures than at high temperatures. Richard et al. (2015) [20] reported that temperature had a strong influence on Venerupis philippinarum clam immune activity. Sudden temperature changes can cause the immune function of shellfish to reduce as the blood's stable state is destroyed. The salinity tolerance level has been studied to observe the long-term and short-term effect of salinity on scallops [21], oysters [22], and Venerupis philippinarum clam [23]. For some shellfish, adaptability to high salinity was better than that to low salinity, while the reverse was true for others.

There have been several studies of clam resources, the ecosystem for clams, seed production and farming systems, identification of pathogens in clams. In Vietnam according to Nguyen Van Hao et al (2011) [24], the study of the presence of Perkinsus sp. on cultured clam (Meretrix Lyrata) in Can Gio area. Besides there was research by Ngo Thi Thu Thao et al (2008), that study some clam pathogens in Ben Tre province and the results show that there were bacteria of Vibrio sp. and Perkinsus sp. parasite caused disease. However, mass mortality has occurred continuously in clam areas. This leads to unsustainable development clam industry. Diseases are one of the major causes of mass mortality in clams. Thus, the objective of this study was (i) to determine the density of Vibrio sp. and Parkinsus sp. in cultured clams and (ii) to evaluate the correlation between pathogenic microorganisms and disease incidence.

\section{Materials and Methods}

\subsection{Collection and Preparation Sample}

Clam samples were collected randomly from February to May 2019 at four provinces: Ben Tre, Tra Vinh, Bac Lieu and Tien Giang. The samples were collected every week and the time of disease outbreak. Total of 30-35 clams/region were collected per site, the clam individuals in this assay all had commercial sizes with an average length of $39.75 \pm 5.92 \mathrm{~mm}$ and an average meat weight of $3.93 \pm 0.33 \mathrm{~g}$. Preferably selecting individuals at the age of one year and older to were collected samples. All samples were kept separately in sterile plastic bags placed in polystyrene foam boxes with ice and analyzed immediately as arrival at the laboratory. All the materials were prepared and treated in the laboratories at Research Institute for Aquaculture No. 2 (RIA 2), Ho Chi Minh City, Vietnam.

\subsection{Determining the Density of Vibrio sp. on Clams Meretrix Lyrata}

In this experiment, Vibrio sp. were cultured in TCBS agar (Thiosulfate Citrate Bile Salt Succrose). Clams split off the casing and were collected to get weighed, washed through physiological saline 3 times, then they shredded the sample. Bacteria in water samples were quantified according to Kock method (1987). Weighting 1 gram of clam sample put into 9 $\mathrm{mL}$ sterile saline solution with $2 \%$ concentration. This solution was serially diluted ten-fold to 10-3; then aspirating $100 \mu \mathrm{L}$ at different concentration and spread it on TCBS agar plates. The colonies were observed and selected after incubating the plates at $28^{\circ} \mathrm{C}$ for 24 hours. Then, TCBS plates were examined for the presence of either yellow or green. The formula for calculating the bacterial density on 1 $\mathrm{mL}$ of sample water is as follows:

$$
A=\frac{X}{K \times V}
$$

Where:

A: is the number of colonies in $1 \mathrm{ml}$ of water $\mathrm{X}$ : the average number of colonies on the plate 
$\mathrm{V}$ : sample volume used

$\mathrm{K}$ : dilution.

\subsection{Isolating the Parasite Perkinsus sp}

According to the method to cultured parasites Perkinsus $s p$. This purpose of the assay to evaluate the infection intensity of Perkinsus sp. on clams Meretrix Lyrata. Antibiotics (Penicilin-Streptomycin-Nystatin) solution was put into a test tube containing Fluid thioglycollate medium (FTM). After weighing the mass of the clam, the clam meat was separated and put into a test tube containing FTM medium. Then the sample was incubated under dark conditions at room temperature for 5-7 days, the sample was centrifuged at $4000 \mathrm{rpm}$ for 10 minutes. Supernatant was removed, pellete was retained. Furthermore, $10 \mathrm{~mL}$ of $2 \mathrm{M}$ $\mathrm{NaOH}$ was put into Falcon for pellete decomposition. After this mixture was incubated in a water bath at $60^{\circ} \mathrm{C}$ for $2-3$ hours to disintegrate the muscle of clams, it was centrifuged at $4000 \mathrm{rpm}$ for 10 minutes. Pellets were retained and centrifuged in $10 \mathrm{~mL} \mathrm{NaCl} 2 \%$ at 4000 rpm for 5 minutes. This process was repeated three times before final pellets were transferred to Eppendorf containing $500 \mu \mathrm{L} \mathrm{NaCl} 2 \%$.

\subsubsection{Determine the Density of Perkinsus sp}

The number of Perkinsus sp. were observed by micropipette to get exactly $20 \mu \mathrm{L}$ small isolated spore samples to lame and can be added to one drop of $4 \%$ Lugol solution. Then, the objectives were observed with $10 \mathrm{x}$ or $40 \mathrm{x}$ microscopy, all Perkinsus spores were observed on moving the slide in zigzag form and counting on lame. After that, the sample was counted repeat five times for each culture sample. In the case of too many spores in the sample, the sample can be diluted with a base with physiological saline or sterile distilled water before counting. Perkinsus spores, when dyed with Lugol, were spherical, blue/dark brown, diameters vary from 10 to $300 \mu \mathrm{m}$.

\subsubsection{Determine the Ratio, the Infection Intensity of Perkinsus sp}

Infection intensity of Perkinsus $s p$. was the number of
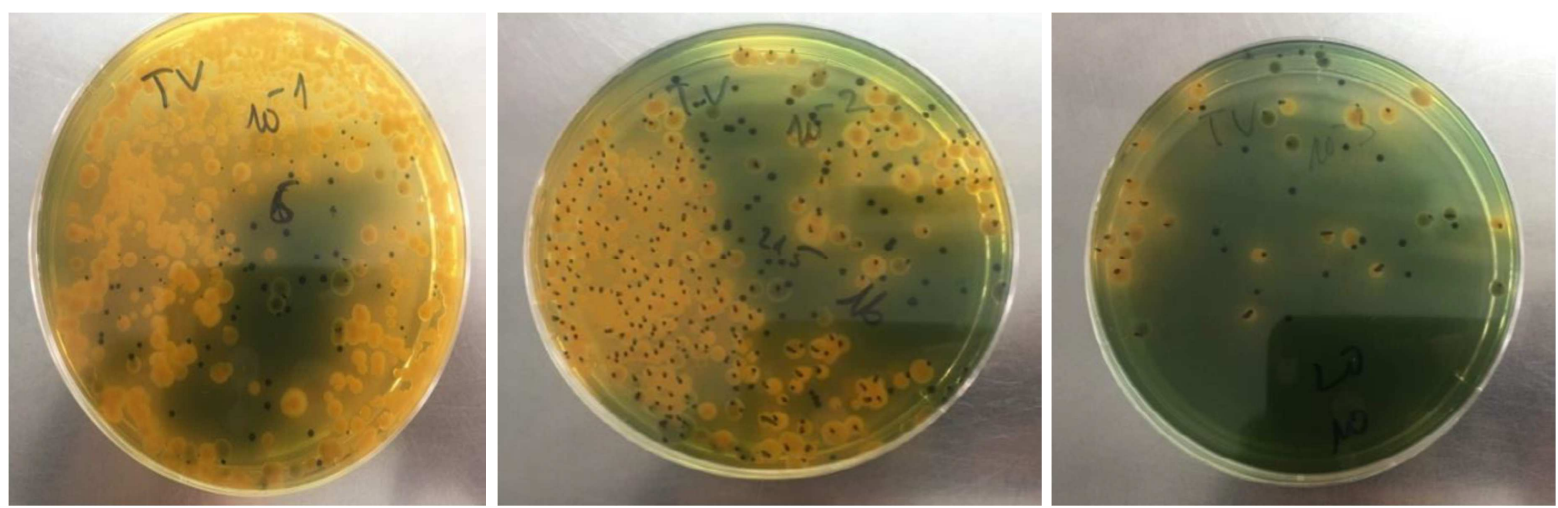

Figure 3. The density of Vibrio sp. with concentration $10^{-1} 10^{-2} 10^{-3}$ of clam farming in Tra Vinh.

In Ben Tre province, the most striking feature is that the number of yellow colonies in March dominated that in April (1.38 $\times 10^{5} \mathrm{CFU} / \mathrm{g}$ and $0.38 \times 10^{5} \mathrm{CFU} / \mathrm{g}$, respectively). spores per gram molluscs that used for culture determined by the formula:

$$
\text { Infection intensity }=\frac{A \times V \times N}{M}
$$

Where:

A: Spores are present in $1 \mathrm{~mL}$ of isolation sample

$\mathrm{V}$ : Volume of samples isolation

$\mathrm{N}$ : Dilution concentration

M: The number of clams used for culture

The ratio of infection was the percentage of infected individuals compared to the number of individuals observed according to the formula:

The rate of infection $=\frac{\text { infected individuals }}{\text { observed individuals }} \times 100$

\subsection{Statistical Analysis}

In this essay, data were reported and presented as mean \pm standard deviation. The statistic was analyzed by SPSS 22 software and Microsoft Excel, especially Two-way ANOVA was used for checking significant difference.

\section{Results and Discussion}

\subsection{Counting the Density of Vibrio sp. on Clam Meretrix Lyrata}

The density of total Vibrio bacteria in the clam samples in our sampling area varied between 0-2.23 x $10^{5}$ (CFU/g). Especially, the density of yellow colonies in the clam samples in our sampling area varied between $0.48 \times 10^{5}-$ $2.24 \times 10^{5}(\mathrm{CFU} / \mathrm{g})$. It can be seen that the density of yellow colonies in March were the highest figure in 3 months and the lowest were in May.

Looking at the information in more details, in Bac Lieu province, the number of yellow colonies in March was about $1.52 \times 10^{5}(\mathrm{CFU} / \mathrm{g})$, compared to $0.48 \times 10^{5}(\mathrm{CFU} / \mathrm{g})$ in May, and only $0.26 \times 10^{5}(\mathrm{CFU} / \mathrm{g})$ in April.
Furthermore, it saw a dramatic increase to $1.04 \times 10^{5}$ (CFU/g) in May. As illustrated, in Tra Vinh, the number of yellow colonies had the highest figure in March about $2.24 \times 10^{5}$ 
(CFU/g), compared to $1.47 \times 10^{5}(\mathrm{CFU} / \mathrm{g})$ in May and only $1.25 \times 10^{5}(\mathrm{CFU} / \mathrm{g})$ in April. In Tien Giang, the number of colonies in April about $2.04 \times 10^{5}(\mathrm{CFU} / \mathrm{g})$ has higher than in May and March $\left(1.48 \times 10^{5} \mathrm{CFU} / \mathrm{g}\right.$ and $1.08 \times 10^{5} \mathrm{CFU} / \mathrm{g}$, respectively).

Besides, the density of green colonies in clam samples varied between $0-0.2 \times 10^{5}(\mathrm{CFU} / \mathrm{g})$. In Bac Lieu and Tra
Vinh, the number of green colonies saw a significant decrease from March to May. Especially, the density of green colonies in Ben Tre and Tien Giang was not stable. The density of green colonies in Ben Tre experienced a sharp increase to $0.2 \times 10^{5}(\mathrm{CFU} / \mathrm{g})$ in May while in March and April showed a dramatic change from $0.12 \times 10^{5}(\mathrm{CFU} / \mathrm{g})$ to $0.06 \times 10^{5}(\mathrm{CFU} / \mathrm{g})$.

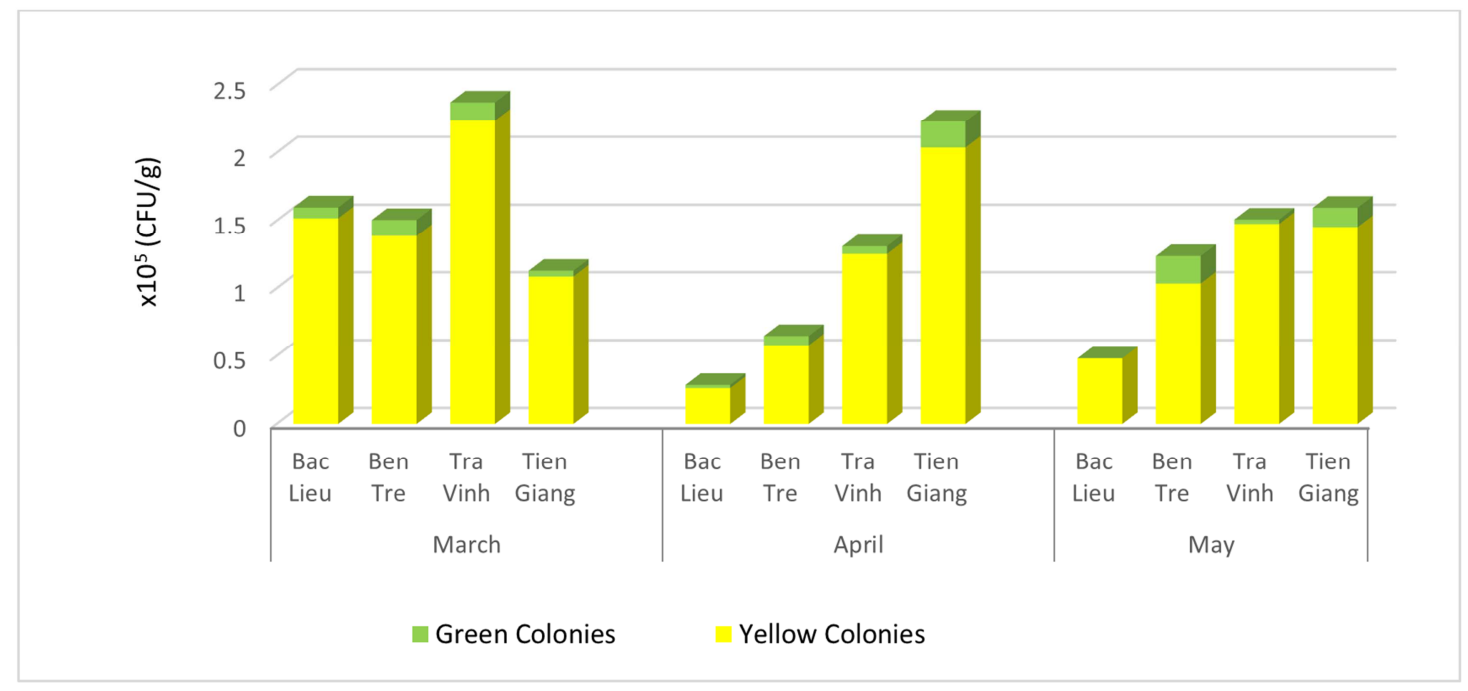

Figure 4. The density of Vibrio sp. on clams in four regions from March to May.

In this essay, Vibrio colonies on TCBS agar appeared either yellow or green or bluish-green. With this, Vibrio counts were obtained from clam samples collected from all four provinces (March-May 2019). The statistical (Appendix 1) analyzed that there was no significant difference in outbreak disease and non-outbreak disease factor on clam samples ( $\mathrm{T}$-value $=-1.928$, $\mathrm{P}>0.05$ ) shown in table 1 . T-test results suggested no significant differences between Vibri $s p$. densities in clam samples in on outbreak disease $(5.04 \pm 4.79)\left(\log _{10} \mathrm{CFU} / \mathrm{g}\right)$ and non-outbreak disease $(5.22 \pm 5.14)\left(\log _{10} \mathrm{CFU} / \mathrm{g}\right)$. (Table 1$)$

In this study, there was no relationship between the density of Vibrio and clam death phenomenon. However, the dead clam phenomenon occurred in Tra Vinh, the rate of dead clam was over $50 \%$ at the time in March this result also quite similar to the survey on coastal clam farms indicated that mass mortality of clam that occurs most often from February to May every year in the research results of Nguyen Van Hao et al, (2018). The majority of clam farmers believe that in temperature $(30.5 \%)$, salinity $(14.3 \%)$, poor water quality $(24.8 \%)$ were the main causes of clam's mass mortality [2].

It was suggested that temperature, salinity and the time of exposure were significantly correlated with mass mortality in clams [3]. In 2013, salinity levels recorded at localities in which clams were dying at a high rate in were $36 \%$ in Nam Dinh, $37 \%$ in Thai Binh, 30-32 \% in Ben Tre. Mass mortality occurred in Bentre in 2013 despite low salinity could be attributed to high water temperature 34 degrees (at low tide). In addition, in laboratory experiments also showed that clams were large (length: $23.2 \pm 0.11 \mathrm{~mm}$ ), cultured at $30 \%$ salinity that led to clam death rate was $79.43 \%$. Another experiment also showed that Vibrio $s p$. bacteria causing infection at 33 degrees and $33 \%$ of salinity caused $100 \%$ death of clams, this author also concluded that environmental factors play a role to the mass mortality of clams.

There was no limit Vibrio sp. on clams affecting clam health. However, according to Moriarty (1998) [25], if the density of Vibrio $s p$. in water samples exceeds $10^{3} \mathrm{CFU} / \mathrm{mL}$, that will badly affect aquatic species. In the sampling periods, the density of Vibrio $s p$. was quite high for an outbreak and non-outbreak disease of clams approximately $10^{5} \mathrm{CFU} / \mathrm{g}$. It was possible to explain the increase in Vibrio $s p$. density at the time of dead clam because of the weakness clams and bad environmental conditions were helped Vibrio growth, that caused the harmful effect of clams.

Table 1. Comparison of the density of Vibrio sp. to the outbreak disease on clams.

\begin{tabular}{lllllc}
\hline Type & Phenomenon & Number of samples & Mean & SD & T-value \\
\hline \multirow{2}{*}{ Clams (CFU/g) } & Non-Outbreak disease & 52 & 5.04 & 4.79 & -1.928 \\
& Outbreak disease & 24 & 5.22 & 5.14 & 0.066 \\
\hline
\end{tabular}

\subsection{Pathological Signs of Perkinsus sp. on Outbreak Disease on Clam}

According to Choi and Park (2005), a typical Perkinsus pathological sign on the surface of the membrane, gastrointestinal tract, legs and gills is caused by a response against inflammation of the host body. The results of clam sample collection and analysis showed that Perkinsus 
infected on clam did not occur typical pathological signs that include shell damage, thin clam, sandy and mud in the gills, membranes appeared white spots and digestive glands turned yellow.
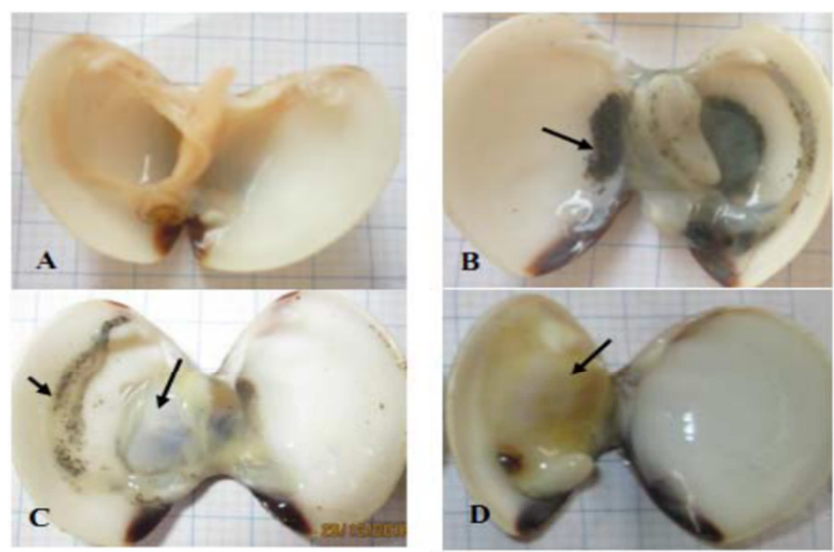

Figure 5. Internal morphology of clam Meretrix Lyrata.

\subsection{Perkinsus Spore Shape and Size After Culturing}

Perkinsus sp. spores isolated from clam samples in four regions after culture in the fluid thioglycollate medium (FTM) that were a cycle and oval shape with a thick crust typical of Perkinsus. When dyeing with Lugol iodine solution, resting spores caught a dark green colour, the diameter varies from 30 to $180 \mu \mathrm{m}$, averaging $73.35 \pm 0.84$ $\mu \mathrm{m}$. Spore diameter is determined by direct measurement on optical microscopy.

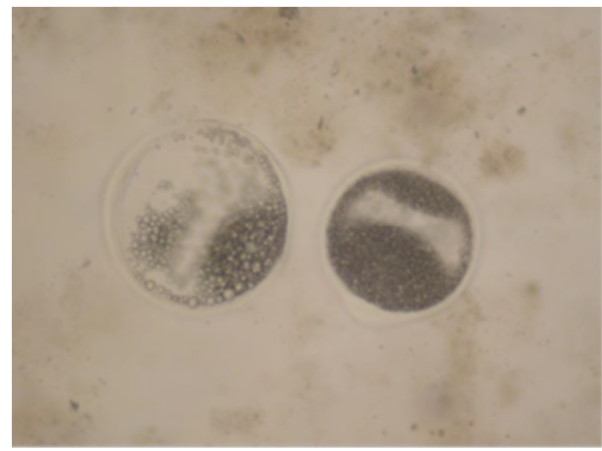

Figure 6. Spore Perkinsus sp. after culturing in FTM medium (10x and 40x).

\subsection{The Ratio and Infection Intensity in Term of Perkinsus sp. on Clam}

The results illustrated that Perkinsus sp. was found in clam cultured in four provinces in the Mekong Delta with an average infection ratio was about 53\%. Looking at the information in more details, in March, the most striking feature is that the proportion of infection Perkinsus on clam in Bac Lieu dominated that in Ben Tre $(90 \%$ and 30\%, respectively). Also, the infection ratio of Perkinsus on clam in Tra Vinh was $70 \%$, which was at least twice as high as that in Tien Giang (around 35\%). In April, the infection ratio of Perkinsus on clam in Tien Giang reached the $60 \%$ mark, with that in Bac Lieu not far behind (45\%). Ben Tre and Tra Vinh had a fairly equal proportion of infection Perkinsus, which made up approximately 50\%. In May, Bac Lieu similar proportion of infection Perkinsus was recorded between Bac Lieu and Ben Tre, at 35\%. Besides, the infection ratio of Perkinsus in Tra Vinh was $80 \%$ and this shows a completely different picture that the proportion of infection Perkinsus in Tien Giang was lower, at 55\%.

Furthermore, the infection intensity was a considerable fluctuation at 4.08-57.43 (spore/gram). The chart illustrates that Bac Lieu has the highest intensity of infection in March (57.43 spores/g) compared to the other three provinces over 3 months. Moreover, Tra Vinh also has a large intensity of infection in March compared to in April (20.68-12.85 spores/g, respectively). In April, the ratio and the intensity of infection in four regions saw a dramatic increase while it experienced a decrease in May. The cause can be in the rainy season that temperature and salinity have significant changes. This reason leads to the parasite unable to live in the host so the ratio and the intensity of infection went down.

The results showed that the prevalence of parasite infection did not differ between the time of clam disease and non-disease. Besides, Perkinsus sp. infection intensity had no difference in the disease clam stage $\left(\mathrm{P}_{\text {value }}>0.05\right)$. At the stage of clam disease, the intensity of infection of this parasite on clam was $15.38 \pm 6.26$ while in the period of non-infected clam was $19.57 \pm 25.28$. Also, the infection intensity of Perkinsus sp. was not positively correlated with mortality of clam in the study area $\left(\mathrm{P}_{\text {value }}>0.05\right)$.

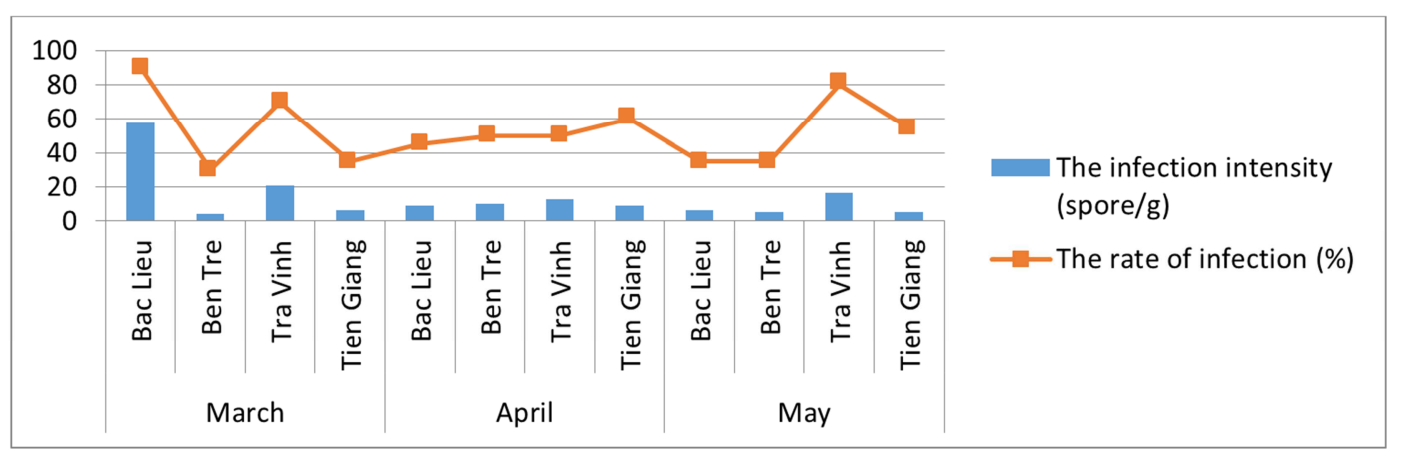

Figure 7. The ratio and infection intensity in term of Perkinsus sp. on clam.

Therefore, with low intensity and infection rate, Perkinsus $s p$. was not considered a cause of clam death in the four surveyed provinces. According to studies on M. Lyrata clams, clams die when the Perkinsus sp. infection ratio was 
over 90\%. According to Soudant et al (2008), many suggested that Perkinsus sp. causing high mortality rates for molluscs when infected with a concentration of $10^{6}$ spores $/ \mathrm{g}$ or more, but at the same time, many studies suggest Perkinsus sp. can kill molluscs cultured at an intensity of only $10^{4}-10^{5}$ spores/g and may differ in different host species.

According to Blackbourn et al (1998); Choi and Park (2005) cells of all Perkinsus sp. (except P. qugwadi) parasites in the host that are susceptible to infection in an FTM environment under anaerobic conditions will increase in size, forming resting spores (hypnospore). This process is also noted on clam samples in some regions in the Mekong Delta when cultured in FTM. The characteristics of shape and colour capture properties when dying with Lugol iodine solution of Perkinsus sp. spores. The isolation was also consistent with the results of many authors' research on Perkinsus.

When compared with the results of other studies, the average ratio of infection of Perkinsus sp. on Meretrix Lyrata clams in four provinces (53\%) were smaller than to the research results of Ngo Thi Thu Thao (2008) on silk clam (Paphia undulate) in Kien Giang and Ba Ria-Vung Tau. Perkinsus sp. also present at a high rate $(67.5-100 \%$ in Kien Giang and $100 \%$ in Ba Ria-Vung Tau) during the study period from January to May 2007. On Manila clam (Ruditapes philippinarum) on Jeju Island - South Korea, Perkinsus sp. also present with the highest rate in March $(86.7 \%)$ and the lowest in September $(6 \%)$. However, the average infection intensity of Perkinsus sp. in three months on clam Meretrix Lyrata in four regions (15.38 \pm 6.26 spores/g) was relatively lower compared to the survey results on silk clam $(10.957$ - 956.996 spores/g in Kien Giang and 98.082 - 204.309 spores/g in Vung Tau). Similarly, the results of this study were also lower than those of Perkinsus sp. on some other clam species in Asia. According to Park et al., (2006) recorded the intensity of infection from 11,000 to 2,000,000 spores/g in Manila clams at Gomsoe Bay - South Korea when infected with Perkinsus olseni at a rate of $100 \%$ and caused high mortality rates. In China, the clam Ruditapes philippinarum was $2,271,883$ spores/g [14]. In Japan, the highest $P$. olseni infection intensity was recorded at 464,000 spores/g and in Thailand an average of 43,530 spores/g [10]. Monitoring results showed Perkinsus sp., incidence and intensity of infection. In clam in four regions high from March is also a time when about $80-100 \%$ of farmers in Tra Vinh and Bac Lieu have dead clams with a high rate (60-90\%) during the study period.

Therefore, from the above research results, Perkinsus $s p$. is a regular presence on clam cultured in four regions in the Mekong Delta. When clam has a high mortality rate in March, with the rate of infection about $90 \%$ and the intensity of infection on 57.42 spores $/ \mathrm{g}$, Perkinsus sp. may be considered a cause of death. However, besides Perkinsus sp., dead clams in four regions during the study period may also be due to changes in environmental and weather factors.
According to farmers' survey information, in the past, natural clam death phenomenon happened twice a year with a low rate of $5-10 \%$ at the time of the season (March and August). From 2007 up to now, the phenomenon of death at the time of the season usually lasts and the rate of dead clam is higher.

Research results of Ngo Thi Thu Thao et al (2012) [26] performed for 5 years on the effects of temperature and salinity on $P$. olseni pathogenicity in $T$. decussates showed on farms or in laboratories, Perkinsus $s p$. develop and cause disease at temperatures above $15^{\circ} \mathrm{C}$ and salinity above $15 \%$. Furthermore, some authors argue that environmental factors are also responsible for increasing the level of contamination of molluscs to Perkinsus sp. On the other hand, they increase Perkinsus' ability to grow and cause high mortality rates for hosts.

\section{Conclusion}

Research results showed that the fluctuation of total Vibrio $s p$. does not follow certain rules during the period from March to May. In Bac Lieu and Tra Vinh provinces, the highest density of Vibrio is in March. However, it is highest in Tien Giang as April. The highest density of Vibrio was $1.52 \times 10^{5} \mathrm{CFU} / \mathrm{g}, 2.24 \times 10^{5} \mathrm{CFU} / \mathrm{g}, 1.38 \times 10^{5} \mathrm{CFU} / \mathrm{g}$ respectively. In March, dead clam occurred in Tra Vinh as a rate of $50 \%$ but no significant difference in outbreak disease and non-outbreak disease factor on clam samples $(\mathrm{P}>0.05)$. The results did not release a clear correlation between Vibrio $s p$. density and clam died. Similarly, the infection intensity fluctuations of Perkinsus sp. also do not follow certain rules as 4.08-57.43 (spore/g) and the prevalence of parasite infection did not relate to the mortality rate of clam samples. It was impossible to conclude that clam died due to Perkinsus parasite because there was no correlation between infection intensity and disease outbreak in the clam samples $(\mathrm{P}>0.05)$. Therefore, dead oranges can be caused by some other factors such as temperature, salinity, and some other environmental factors. To avoid damage to clam farming, farms need to select suitable spawning sites, stocking time to minimize the negative impact of environmental factors, and regular screening for Vibrio sp. and Perkinsus sp. to promptly solve the problem when the monitoring indicators exceed the recommended threshold which can cause clam disease.

\section{References}

[1] Bùi Đắc Thuyết, 2013. Hiện trạng nghề nuôi ngao tại một số tỉnh ven biển miền Bắc và Bắc Trung Bộ, Việt Nam. Tạp chí khoa học và phát triển $11,972-980$.

[2] Yun-Kyong Shin, Kim Yoon, Chung Ee-Yung, Hur SungBum. Temperature and salinity tolerance of the manila clam, ruditapes philippinarum. Korean J. Fish. Aquat. Sci., 33 (2000), pp. 213-218.

[3] Bùi Ngọc Thanh, 2014. Báo cáo tổng kết đề tài:"Nghiên cứu các biện pháp kỹ thuật và quản lý nhằm góp phần ổn định nghề nuôi nghêu thương phẩm ở Việt Nam", Viện Nghiên cứu Nuôi trồng Thủy sản I. 
[4] OIE, 2009. Manual of Diagnostic Tests for Aquatic Animals. Part 2 - Section 2.2 - Disease of Molluscs.

[5] Bower, S. M., 2009. Synopsis of Infectious Diseases and Parasites of Commercially Exploited Shellfish: Vibrio spp. (Larval and Juvenile Vibriosis) of Clams

[6] Elston, R. A., 1990. Mollusc diseases: guide for the shellfish farmer. Washington Sea Grant Program, University of Washington Press, Seattle, 73 pp. United State of America

[7] Go'mez-Leo'n, J., Villamil, L., Lemos, M. L., Novoa, B., Figueras, A., 2005. Isolation of Vibrio alginolyticus and Vibrio splendidus from Aquacultured Carpet Shell Clam (Ruditapes decussatus) Larvae Associated with Mass Mortalities. Applied and Environmental Microbiology 71, 98104.

[8] Bondad-Reantaso, M. G., McGladdery, S. E., East, I., Subasinghe, R. P., 2001. Asia Diagnostic guide to aquatic animal diseases. FAO Fisheries Technical Paper. No. 402/2: 125-128.

[9] Paillard, C., Maes, P., Oubella, R., 1994. Brown ring disease in clam. Annual Review of Fish Diseases 4, 219-240.

[10] Park, K. I., Paillard, C., Chevalier, P. L., Choi, K. S., 2006. Report on the occurrence of brown ring disease (BRD) in Manila clam, Ruditapes philippinarum, on the west coast of Korea. Aquaculture 255, 610-613.

[11] Paillard, C., Le Roux, F., Borreg, J. J., 2004. Bacterial disease in marine bivalves, a review of recent studies: Trends and evolution. Aquatic Living Resources 17, 477-498.

[12] Yue, X., Liu, B., Xiang, J., Jia, J., 2010. Identification and characterization of the pathogenic effect of a Vibrio parahaemolyticus-related bacterium isolated from clam Meretrix Meretrix with mass mortality. J Invertebr Pathol 103.

[13] Villalba A., Casas S. M., Lopez C., Carballal M. J., 2005. Study of Perkinosis in the carpet shell clam Tapes decussates in Galicia (NW Spain). II. Temporal pattern of disease dynamics and association with clam mortality. Disease of Aquatic Organism 65: 257-267.

[14] Blackbourn J., Bower S. M., Meyer G. R., 1998. Perkinsus qugwadi sp. nov. (incertae sedis), a pathogenic protozoan parasite of Japanese scallops, Patinopecten yessoensis, cultured in British Columbia, Canada. Canadian Journal Zoology 76: 942-953.

[15] Choi, K. S., Park K. I., Cho M. and Soudant P., 2005. Diagnosis, pathology, and taxonomy of Perkinsus sp. isolated from the Manila clam Ruditapes philippinarum in Korea. Journal of the Korean Aquaculture Society 18: 207-214.
[16] Ngô Thị Thu Thảo, 2008. Một số đặc điểm của ký sinh trùng Perkinsus sp. lây nhiễm trên nghêu lụa Paphia undulata ở Kiên Giang và Bà Ria - Vũng Tàu. Tạp chí Khoa học - Đại học Cần Thơ 1: 222-230

[17] Almeida M., Berthe F., Thébault A., Dinis M. T., 1999. Whole clam culture as a quantitative diagnostic procedure of Perkinsus atlanticus (Apicomplexa, Perkinsea) in clams Ruditapes decussatus. Aquaculture 177: 325-332.

[18] Kocovsky and Carline, 2001 P. M. Kocovsky, R. F. Carline. Influence of extreme temperatures on consumption and condition of walleyes in pymatuning sanctuary, pennsylvania N. Am. J. Fish. Manage., 21 (1) (2001), pp. 198-207

[19] Lin and Xu, 1997, Zhuojun Lin, Z. Xu. Effects of temperature and salinity on the growth and development of Meretrix Lyrata J. Fujian Fish., 1 (1997), pp. 27-33 (In Chinese)

[20] Richard et al., 2015 G. Richard, C. Le Bris, C. Lambert, F. C. Guérard, C. Paillard. Immune responses of phenoloxidase and superoxide dismutase in the Manila clam Venerupis philippinarum challenged with Vibrio tapetis - part II: combined effect of temperature and two Vibrio tapetis strains Fish Shellfish Immunol., 44 (2015), pp. 79-87

[21] Bergman et al., 1996 C. Bergman, J. J. Parsons, C. Couturier. Tolerance of the giant sea scallop Placopecten magellanicus, to low salinity Bull. Aquac. Assoc. Canada, 96-93 (1996), pp. $62-64$

[22] Hildreth and Stickle, 1980 E. Hildreth, B. Stickle. The effect of temperature and salinity on the osmotic composition of the southern oyater Drill, Thais heaemastoma Univ. Chicago J., 159 (1) (1980)

[23] Sinh, L. X., Đỗ Minh, C., Huỳnh Văn, H., Trương Quốc, P., 2007. Nghiên cứu thị trường nghêu ở tỉnh Trà Vinh trong mối liên hệ với các tỉnh ven biển phía Nam. Tạp chí Khoa học 8 , $38-46$.

[24] Nguyễn Văn Hảo, Ngô Thị Ngọc Thủy, Tiêu Thanh Tươi, Hoàng Thị Hiền, Phạm Lâm Chính Văn và Nguyễn Vy Vân, 2011. Sự hiện diện của Perkinsus sp. trên nghêu (Meretrix Lyrata) tại vùng biển Cần Giờ - thành phố Hồ Chí Minh. Tạp chí Nông nghiệp và Phát triển Nông thôn tháng 12/2011, 97105.

[25] Moriarty, D. J. W. (1998). Control of luminous Vibrio species in penaeid aquaculture ponds. Aquaculture, 164 (1-4), 351358.

[26] Ngô Thị Thu Thảo và Lâm Thị Quang Mẫn, 2012. Ảnh hưởng cứa dộ mặn và 4 thời gian phơi bãi đến sinh trưởng và tỷ lệ sống của nghêu (Meretrix Lyrata) Tạp chí Khoa học Trường Đại học Cần Thơ, 123-130. 